\title{
Community Based Tourism Development as a Community Economic Development Strategies in the District of South Middle East NTT
}

\author{
Zainuddin Adang Djaha*, Hapsa Usman, Deetje Wieske Manuain \\ Accounting Department \\ Kupang State Polytechnic \\ Kupang, Indonesia \\ *adangdjaha31@gmail.com, hapsagemini1978@gmail.com, decewm@yahoo.com
}

\begin{abstract}
The research method used is descriptive qualitative, with research and development procedures developed by Borg and Gall with adaptations and modifications in stages. The research is planned for one year. The technique of collecting data is through the stages of observation, interviews and focus group discussions and documentation. Research activities consist of preliminary studies, conceptual modeling, validation and revision, and model testing. Researchers act as active instruments in an effort to collect data in the field. The research subjects were the head and field expert staff of the Culture, Tourism, Youth and Sports Service as key informants. Supporting informants are tourists, community leaders and community actors who live around tourist objects in the South Central East Regency. Data analysis use interactive analysis model from Miles and Huberman. The results of this study indicate: (1) The efforts of the South Central East Regency Government in developing CBT as a strategy for community economic empowerment are through: (a) Tourism awareness socialization development programs and tourist destinations, (b) tourism marketing development programs, and (c) partnership development. (2) Types of tourism that have the potential to be developed into community-based tourism in the South Central East Regency include nature tourism, cultural tourism, educational tourism, handicraft and culinary tourism. (3) The factors inhibiting the development of CBT in the South Middle East District are: (a) infrastructure that is not yet supportive, (b) community participation in developing tourism is still low, and (c) partnerships have not been maximally established. (4) There is no collaboration between Higher Education Institutions, Local Governments and Communities in developing CBT as a strategy for community economic empowerment.
\end{abstract}

Keywords-community based tourisme, economic, development, district TTS

\section{INTRODUCTION}

Tourism according to Spillane [1] in Rahayu, Dewi, and Fitriana [2] is a trip from one place to another, temporary, carried out individually or in groups, as an effort to find balance / harmony and happiness with the environment in the social, cultural, natural and environmental dimensions science. Indonesian tourism is tourism that comes from, by and for the people, therefore in tourism development planning it must involve the local community (local) especially those around tourist destinations, because local people are the owners and know more about these destinations [3].

The application of community based tourism (CBT) is an approach to tourism development with participatory planning. The definition of CBT is: a tourism model that involves local communities by providing opportunities to manage and develop tourism, either directly or indirectly with links to the tourism industry or business, so that the distribution of profits is evenly distributed to communities in rural/coastal areas and small islands [3].

Thus CBT is a tourism development approach that emphasizes the active role of local communities (whether directly involved in the tourism industry or not). This involvement is in the form of providing opportunities (access) in tourism management and development which leads to community empowerment, including in profit sharing from tourism activities [3]. A critical form of concern is the idea of tourism development which often ignores the rights of local communities in tourist destinations [3].

South Central East Regency is one of the regencies in East Nusa Tenggara Province. Referring to Law Number 32 Year 2004 and Law Number 33 Year 2004 [4], East Tengah Selatan as a district has its own authority to manage the resources contained in its territory, including the potential resources of its tourism sector. The South Central East Regency has a tourism sector with the potential to be developed and marketed, starting from the coast, culture, tourism, highlands. Some of the tourist destinations in the South Central East Regency are as follows. 
South Central are as follows:

- Kolbano Beach In Kolbano Sub-District

- Oetune Beach in South Amanuban District

- Bitan Beach in Koalin District

- Nunkolo Beach in Nunkolo District

- Bukit Cinta in West Amanuban Sub-District

- Mount Mutis in Fatumnasi District

- Futuat Beach in Kotolin District

- Oehala Waterfall in Soe District

- Fatumnasi Nature Tourism, Fatumnasi District

- Fatukopa Hill In Fatukopa District

- Tegepe waterfall in North Mollo District

- Lavender Flower Forest in South Mollo District

- Bu'at tourist park in South Mollo District

- Agro Tourism, Central Mollo District

- Noinbila Waterfall, South Mollo District

- Bola Palelo in Central Mollo District

- Oelemefun Waterfall in Mollo Tengah District

- Penkase in Kolbano District

- Beatriks Park In Soe City

- Danau Supul in Strongnana District

- Lake Nausus In North Mollo District

- Tourism Fatuulan In Kie Sub-District

- Mount Kona Ba'u In Kie District

Source: South Central East Regency Regional Regulation No.1 of 2012 [5]

All of the tourism objects above are under the control of the Regency government through the Culture, Youth and Sports Office of the South Middle East Regency. This means that the management and development of tourism objects still rely on incentives and initiatives from the local government, while the management by the private sector and the community is only partial, such as supporting facilities at waterfalls and lakes and tourist beaches which are carried out independently by the surrounding community. The various types of tourism objects in the Middle East and South can be a big potential and economic investment in the future, be it for the government, private sector and the surrounding community. But of course various policies are needed the right protection so that continuity is always created among stakeholders In connection with the efforts of the South Middle East regional government to develop tourism in their regions, on the ground looks different.

The tourism of the South Middle East which has high potential is not able to compete with its neighbouring areas, where other districts have a higher tourism object capability compared to the South Middle East which has decreased due to several constraints. Among them are having more difficult road access and accommodation. Seeing this data, many questions will arise, why areas with high tourism capacity are not able to compete with other regions. The large number of tourism potentials in the South Central East Regency should make Soe City in terms of tourism, or at least be able to compete with its neighbouring areas of one province. However, the reality on the ground shows a setback in terms of local tourism development. Apart from the 23 tourism objects mentioned in Perda No.1 / 2012 [5], there are actually several other tourism objects that have high economic potential, such as the Mollo Kingdom which is located in Mollo Utara District. Lake Nausus is a lake located in the South Middle East Region of Soe City, which is a vital means for agricultural activities under it. As the only lake in the Soe area, the lack of promotion and the seriousness of development from related parties make this tour seem marginalized from many other tours in East Nusa Tenggara Province.

In addition, there are still tours of Kolbano Beach that have not been maximized and several others. As an agricultural area, the South Central East Regency, the majority of the population is still working in the agricultural sector. The natural potential of the South Central East Regency should be well preserved. Development in the technology industry is possible, but in order to support regional food self-sufficiency. This cannot be used as a main priority of development. One of the industries that can go hand in hand with the concept of an agricultural area in the South Central East Regency is the development of the tourism industry.

The synergy of tourism, agriculture and livestock as an environmentally friendly industry. One of them can be realized through the concept of a tourism village, such as Kolbano Tourism Village, Koalin Tourism Village, Fatumnasi Tourism Village, and so on. The high tourism potential in the SOE area should be optimized, not as a regional income potential, but as an effort to preserve the regional culture that has begun to be abandoned. As one of the main motivators for industrial development, tourism.

The regional government of the south and Middle East district needs its role both to manage and market tourism products so that they can become a potential source of income for the region. Through its various policy breakthroughs, it is hoped that the local government will be able to embrace various stakeholders for the sustainability of a competitive and sustainable tourism industry based on community empowerment. Based on the description above, this article will discuss the development of community-based tourism as a strategy for economic empowerment of the Soe community in 
the southern Middle East district of East Nusa Tenggara province.

\section{RESEARCH METHODS}

The research method used is descriptive qualitative, with research and development procedures developed by Borg and Gall with adaptations and modifications in stages. The research is planned for one year. The technique of collecting data is through the stages of observation, interviews and focus group discussions and documentation. Research activities consist of preliminary studies, conceptual modelling, validation and revision, and model testing. Researchers act as active instruments in an effort to collect data in the field. The research subjects were the head and field expert staff of the Culture, Tourism, Youth and Sports Service as key informants. Supporting informants are tourists, community leaders and community actors who live around tourist objects in the South Central East Regency. Data analysis using interactive analysis model from Miles and Huberman.

\section{RESULTS AND DISCUSSION}

Building NTT as one of the gates and centers for national tourism development (Ring of Beauty)". Therefore this mission is directed at efforts to optimize its utilization in the context of developing the tourism sector with a regional approach through tourism estate as the prime mover of the NTT economy. Its strategic geographic location allows NTT to become one of the gates and centers for national tourism development.

Potential Tourism Attractions (DTW) are classified based on Tourism Themes such as Nature, Culture, Artificial and Special Interests. However, the identification of destinations in 2019 from the NTT Province Tourism and Creative Economy Office shows that the distribution of DTW in 22 districts / cities is still divided into 3 categories, namely nature, culture and special interests. The total number of DTWs in NTT is 1,305 DTW with details of 643 or $49 \%$ of DTW Alam, 536 or $41 \%$ of DTW Budaya, and 126 or $10 \%$ of Special Interest DTW (See Figure 1)

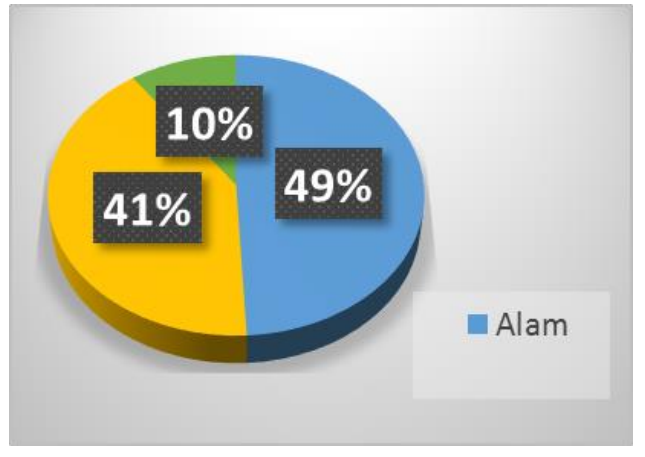

Fig. 1. Potential of DTW in East Nusa Tenggara Province.

Source: NTT Province Tourism and Creative Economy Office [6].
Each district / city in East Nusa Tenggara has a different number of DTWs for each district / city whose distribution is illustrated in the following figure 2 .

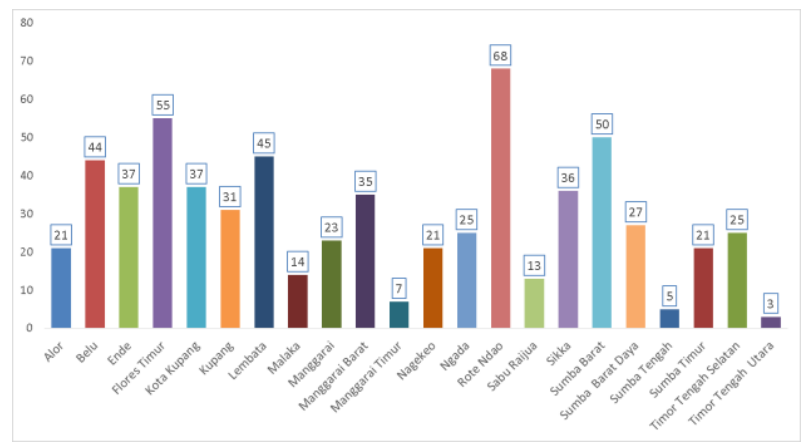

Fig. 2. Comparison of the number of potential tourism attractions in NTT Province based on natural tourism themes.

Community empowerment is interpreted as an effort to strengthen the power or empowerment of powerless groups of people, usually those who belong to the marginalized community. Sinclair [7] states that tourism can provide benefits in the form of strengthening the local economy, which include foreign exchange, additional income to the community, and job opportunities that can be captured by the community. The business sector in tourism, such as accommodation, transportation, and others, can contribute to stimulating the local, regional and national economy. Murphy and Dawyer et al. in Sunaryo [8] state that tourism development must be a community-based activity. With the main factors being the resources and the uniqueness of the local community, both in the form of physical and non-physical elements (traditions and culture) attached to the community, it must be the prime mover in tourism. Sunaryo [8] states that to realize tourism development runs well and is well managed, the most basic thing to do is how to facilitate wide involvement of local communities in the development process and maximizing the social and economic benefits of tourism activities for local communities. The local community has an equally important position as a stakeholder in tourism development, apart from the government and private industry.

Based on the concept of community empowerment in tourism development, community empowerment efforts through tourism in essence should be directed at the following points. 1. Increased capacity, role and community initiatives for tourism development. 2. The increased position and quality of community involvement / participation. 3 . The increased value of the positive benefits of tourism development for the economic welfare of the community. 4. The increased community's ability to travel [8]. Sunaryo [8] further stated that in the development of tourism which is oriented towards community empowerment, it is an issue of current tourism development strategies. In the realm of tourism science, this strategy is known as community based tourism (CBT) or community-based tourism. 
In principle, this $\mathrm{CBT}$ construction is one of the important and critical ideas in the development of the conventional tourism development theory (growth oriented model) which has often received a lot of criticism for neglecting rights and marginalizing local communities from tourism activities in a destination. Murphy in Sunaryo [8] states that in essence tourism development cannot be separated from the resources and uniqueness of local communities, both in the form of physical and non-physical elements (traditions and culture), which are the main driving elements of tourism activities themselves. Tourism should be viewed as a community based activity. The definition of community-based tourism is as follows.

- A form of tourism governance that provides opportunities for local communities to control and be actively involved in the management and development of existing tourism.

- A form of tourism governance that can provide opportunities for people who are directly involved in tourism businesses can also benefit from existing tourism.

- A form of tourism that demands systematic and democratic empowerment and equitable distribution of benefits to disadvantaged communities in destinations. Community-based tourism is closely related to ensuring the active participation of local communities in existing tourism development.

Community participation in tourism consists of two perspectives, namely community participation in the decisionmaking process and participation related to the distribution of benefits received by the community from tourism development. Therefore, there are basically three main principles in the community-based tourism development planning strategy, namely: Involving community members in decision making. 2. There is certainty that local communities will receive benefits from tourism activities. 3. Tourism education for local communities [8].

Suansri [9] mentions several principles of CBT that must be carried out, namely: (1) recognizing, supporting, and promoting community ownership in tourism, (2) involving community members from every stage of tourism development in various aspects, (3) promoting pride the community concerned, (4) improving the quality of life, (5) ensuring environmental sustainability, (6) protecting the characteristics (uniqueness) and culture of the local community, (7) develops cross-cultural learning, (8) respects cultural differences and human dignity, (9) distributes profits and benefits proportionately to community members, (10) contributes a certain percentage of income earned for community development, and (11) emphasize the authenticity of the community's relationship with the environment.

\section{CONCLUSION AND RECOMMENDATION}

\section{A. Conclusion}

Based on the description above, it can be concluded: (1) The efforts of the South Central East Regency Government in developing CBT as a strategy for community economic empowerment are through: (a) Tourism awareness socialization development programs and tourist destinations, (b) tourism marketing development programs, and (c) Partnership development program. (2) Types of tourism that have the potential to be developed into community-based tourism in the South Central East Regency include nature tourism, cultural tourism, educational tourism, handicraft and culinary tourism. (3) The factors inhibiting the development of CBT in the South Middle East Regency are: (a) infrastructure that is not yet supportive, (b) community participation in developing tourism is still low, and (c) partnerships have not been maximally established. (4) There is no collaboration between Higher Education Institutions, Local Governments and Communities in developing CBT as a strategy for community economic empowerment.

\section{B. Recommendation}

In the development of CBT, there are several suggestions that can be implemented by the South Central East Regency Government, namely: (1) Increasing the participation of all stakeholders, including the community, in developing tourism potential in the Middle East as well. (2) Increasing the budget for destinations and infrastructure for tourism development through creative and innovative activities through cultural competition events, while still paying attention to regional characteristics. (3) Increasing the quantity and quality of human resources to support the tourism sector. (4) Increasing efforts to build public awareness of the importance of development through training and workshops and socialization of tourism awareness.

\section{REFERENCES}

[1] J.J. Spillane, Ekonomi Pariwisata Sejarah dan Prospeknya. Yogyakarta: Kanisius, 1987

[2] S. Rahayu, U. Dewi, dan K.N. Fitriana, "Pengembangan Community Based Tourism Sebagai Strategi Pemberdayaan Ekonomi Masyarakat D Kabupaten Kulon Progo, Daerah Istimewa Yogyakarta," Jurnal Penelitian Humaniora UNY, vol. 21, no. (1), p. 124561, 2015.

[3] Nurdin, "Strategi Pengembangan Pariwisata Berbasis Masyarakat Di Pulau Samalona, Makassar,” Jumpa, vol. 3, no. (1), pp. 175-189, 2016.

[4] Undang-Undang Nomor 32 tahun 2004 tentang Pemerintahan Daerah.

[5] Peraturan Daerah Kabupaten Timur Tengah Selatan Nomor 1 Tahun 2012 tentang Rencana Tata Ruang Kabupaten Timur Tengah Selatan

[6] Badan Pusat Statistik, Provinsi NTT Dalam Angka 2019, NTT.

[7] M.T. Sinclair, "Tourism and economic development: A survey," The journal of development studies, vol. 34, no. (5), pp. 1-51,1998.

[8] B. Sunaryo, Kebijakan Pembangunan Destinasi Pariwisata Konsep dan Aplikasinya di Indonesia. Yogyakarta: Gava Media, 2013.

[9] P. Suansri, Community based tourism handbook. Bangkok: Responsible Ecological Social Tour-REST, 2003. 